\title{
Studies on the Location, Anatomy and the Histology of the Endocrine Glands of Xenentodon cancila (Ham.)
}

By

\author{
O.P. Gupta and R. K. Shrivastava \\ Department of Zoology University of Saugar \\ $S A G A R$ (M. P.) INDIA. \\ - Received for publication, December 2, 1970-
}

\section{Introduction}

The present paper describes the various endocrine glands found in the body of the Xenentodon. Each gland has been studied morphologically and histologically by both general as well as special staining procedures.

\section{Material and Methods}

The fishes were collected fresh from the local Sagar lake and the endocrine tissue was dissected out carefully after having washed it in the physiological saline $(0.2 \%)$. They were fixed in proper fixatives and stained as follows:

Pituitary

Pineal

Thyroid

Thymus

Corpuscle of Stannius
-Delafield's (1885) Haematoxylin and eosin stain. Gomori's (1953) Aldehyde fuchsin as recommended by Dawson (1953). Mallory's (1936) Triple stain. Romeis (1948) Magenta and resorcinol stain.

-Himes and Moriber's (1956) Napthol yellow S stain.

Lillie's (1951) Allochrome stain.

Pal-Weigert (Clark and Ward, 1934) stain.

- Heidenhain's (1905) Azan stain. Mallory's (1936) triple stain.

-Heidenhain's (1905) Azan stain.

- Himes and Moriber's (1956) Napthol yellow S stain, Lillie's (1951) Allochrome stain. 
Inter-renal body -Wiesel's (1902) Toluidene blue and safranin stain. Ultimobranchial -Mallory's (1936) triple stain.

body

Urophysis -Korson's (1951) Methyl green and orange G stain.

Islets of

Langerhans

-Bailey's (1937 c) Orange $G$ and resorcin stain.

Gomori's (1941) Chrome-alum and phloxine stain.

\section{Observations and Discussion}

The endocrine glands in Xenentodon as could be detected during the present study are described below as to their topography and histological details.

1. Pituitary body (Fig. 1)

The pituitary or hypophysis (Gupta, $1970 \mathrm{~d}$ ) is a round conical structure situated just behind the optic chiasma on the ventral side of the brain. It is attached to the infundibulum by an ill emphasized stalk and covered by the menengial membrane. The stalk is continued into the main mass of the hypophysis as neurophypophysis. The third ventricle continues into the stalk as the infundibular recess (INF. R. Fig. 1) and its lining is formed of ependymal cells. The ependymal layer is several cells in thickness.

Gorbman in his recent publication (1965) recommends the usage of the terminology of Green (1951) and in the present text the same terminology has been followed. The hypophysis is divided into a glandular (Adenohypophysis) and a nervous component (Neurohypophysis or pars nervosa). The glandular portion is further divisible into pars distalis and pars intermedia.

(i) Pars distalis:

The pars distalis, which is embryologically derived from the buccal epithelium, is differentiated into two lobes histologically:

(a) Rostral pars distalis (pars anterius)

(b) Proximal pars distalis (übergangsteil)

(a) Rostral pars distalis (RPD. Fig. 1): It is present on the antero-dorsal side of the pituitary gland. It is the smallest component of the gland. Acidophils are the only cell type present in this region and appear pinkish with Aldehyde fuchsin and orange with Mallory's triple stain.

(b) Proximal pars distalis (PPD. Fig. 1): It is the largest portion of the pituitary gland and surrounds a comparatively smaller portion-the pars intermedia. There is no connective tissue present separating the glandular region from the other. They can only be distinguished by their different cell types. Chief cells of proximal 
pars distalis are basophils. They stain purple with Aldehyde fuchsin and blue with Mallory's triple stain. Along with the basophils, a good number of acidophils and a few chromophobes are also present. The acidophils of this region are similar to those of the rostral pars distalis in their staining reactions.

(ii) Pars intermedia (PI. Fig. 1): This region, which is surrounded by proximal pars distalis, is divided into a number of lobules due to the extreme ramification of pars nervosa. The lobules contain only acidophils which are not similar to those present in rostral and proximal pars distalis. They stain light pink with Aldehyde fuchsin and light orange with Mallory.

Pars nervosa:

The nervous component or pars nervosa (PN. Fig. 1) is made up of fibro-cellular tissue containing blood capillaries and scattered nuclei of pituicytes. It branches extensively in pars anterius (rostral pars distalis) and übergangsteil (proximal pars distalis) and its main stem arborises in the pars intermedia. The structure as described above has been described from the animals collected during the month of December.

The pituitary body of Xenentodon confirms to the general teleost pattern. However, the pars intermedia is centrally situated and surrounded by proximal pars distalis. Such a condition has so far been reported in only a few teleosts e.g. Ambassia ranga (Kaur, 1968) and in Nandus nandus (Raizada, 1970).

2. The pineal body (Figs. $10 \& 11)$ :

The pineal body is an elongated, folded glandular structure lying on the dorsal side of the diencephalon. It is made up of ependymal cells placed on a basement or limiting membrane. Some of the ependymal cells are modified into the neurosensory cells. The neurosensory cells (NSC. Fig. 10) are elongated and show tail-like processes on both ends. The inner process forms a sort of sensory hair while the outer processes are continued into the pineal nerve. The remaining ependymal cells function as supporting cells. Large-sized cells near the limiting membrane are the ganglion cells (GANG. C. Fig. 10). An important feature in the pineal body of Xenentodon is the presence of numerous pigment granules in the pineal cells. The lumen of the pineal body is filled with rounded cells which appear to have been derived from the general ventricular (ependymal) epithelium.

3. Thyroid (Fig. 2) :

The thyroid in Xenentodon lies as scattered follicles (TH. FOL. 
Fig. 2) round the ventral aorta. The follicle are ovoid in shape and have a regular cuboid epithelium. There is a thin connective tissue membrane (CON. M. Fig. 2) covering the follicles and minute blood vessels are seen through it. The nuclei are oval and practically fill the cell. Inside, the follicles are found fully filled with colloid (COL. Fig. 2). Minute black granules are visible in the collaid. The cells and their nuclei are coloured orange red while the colloid is stained yellowish green with Mallory's triple stain. With the Heidenhain's (1905) azan stain, nuclei are blue, cytoplasm and the colloid take a red colour.

\section{Thymus (Fig. 3) :}

The thymus is present inside the pharynx dorsal to the branchial region on each side. It is covered by the mucous membrane (M. MEM. Fig. 3) of the branchial cavity. It is a rod-like structure which appears pearshaped. In the cyprinidae, it is swollen and tends to become embedded in adjacent connective tissue (Hammer, 1908). In Carassius it has a peduncle (Hammer, 1908). The thymus has a simple structure in Xenentodon. It is formed of a simple superificial epithelium. No mucous cells were seen in the superficial epithelium but they are abundantly present in the branchial epithelium. Internally it is filled with a mass of cells (C. MAS. Fig. 3) with round nuclei. At places the cells are arranged into cords. There are no connective tissue septa. The differentiation between the cortial and medullary cells is not very prominent.

\section{Corpuscles of Stannius (Fig. 4):}

The corpuscles of Stannius in Xenentodon are round to ovoid yellow bodies found embedded in the hinder part of the kidney. They are mostly two in number, one on each side of the median line. In some specimens 4 to 6 corpuscles of Stannius were found of which a pair was larger in size and coloured bright yellow, while the remaining ones were smaller in size and their appearance was. dull yellow.

Each corpusle of Stannius is covered by a thin membrane (COV. M. Fig. 4) consisting of flattened cells. A fibrous structure has been described in the capsular wall in Anguilla (Vincent and Curtis, 1927). The capsular wall continues inside to form connective tissue septa lining the lobes as in Anguilla. However, in Xenentodon the outer capsular wall is made up of flattened cells. Just internal to the outer membrane are seen the epithelial cells (EP. C. Fig. 4). The epithelium grows inwards into a number of lamellae which fill most of the internal lumen. Only minute spaces are seen here and there 
between the lamellae. The lamellae are well supplied with blood eapillaries. The nuclei of the cells are oval and generally contain chromatin particles. The allochrome (Lillie, 1951) staining of the lamellae shows minute secretory granules in the cytoplasm.

Tho corpuscles of Stannius are special structures found in the tolossteans. Giacomini (1934) calls thom as postorior intorranal body. The corpuseles of Stannius have beon homologisad with tho supra or adranal cortex of the mammals but their exact function is still disputed.

\section{Interrenal body (Fig. 9) :}

The interrenal body is described along with the excretory organs (Gupta \& Shrivastava, 1971).

7. Post-branchial body or Ultimobranchial body (Fig. 5) :

It lies between the oesophagus (OES. M. Fig. 5) and the sinus venosus (S. V. Fig. 5). In the $35 \mathrm{~mm}$. fish, the ultimobranchial body is quite simple forming only a row of cells between the oesophagus and sinus venosus. It appears as though it is squeezed between the oesophagus and sinus venosus. However in the $110 \mathrm{~mm}$. fish the gland appears to be hypertrophied (ULTI. C. Fig. 5). There is ample space between the oesophagus and the sinus venosus and the cells are greatly enlarged. These cells differ in shape, some are oblong while others are round, spherical or ovoid. The smaller sized cells have a simple round nucleus but in the larger cells the nucleus shows a number of lobes. There are large granular structures inside the nucleus. The cytoplasm is not uniform. Ridge-like structures are seen here and there. Numerous blood capillaries are scattered among these cells.

According to Rasquin and Rosenbloom (1954) the function of the ultimobranchial gland is similar to the parathyroid. This interesting investigation, however, was based on the histological study of the endocrine organs of the eyed forms of Astyanax mexicanus maintained in total darkness for periods of 4 months to $2^{1 / 2}$ years. Krawarik (1936) was the first to study the histological details of the ultimobranchial gland.

The ultimobranchial body has been variously named, as the suprapericardial body, ultimobranchial body or post-branchial body. Giacomini (1934) has studied their structure in a number of fishes. According to him these cells have minute granules which cannot be homologised with the thyroidean colloid. 
8. Urophysis (Figs. 6, 7 and 8):

The urophysis in fishes has been studied by a number of workers like Dahlgren (1914), Favaro (1925), Enami (1959) and Friedberg (1959), still much remains to be done. Recently two good reviews have been published by Gunnar Fridberg (1962, '63). There has been some controversy regarding the terminology to be used in the description of the caudal neurosecretory system. Friedberg (1962) favours the use of the term 'Urophysis medullae spinalis.'

The urophysis in the Xenentodon is situated at the caudal end of the spinal cord (Gupta $1970 \mathrm{~d}$ ), a few $\mathrm{mm}$. in front of the termination of spinal cord. This ventral enlargement of the spinal cord is a sac-like structure measuring about 5 to $7 \mathrm{~mm}$. As uswal the caudal neurosecretory system is made up of two parts :

i) Neurosecretory or Dahlgren cells

ii) Urophysis proper

(i) Neurosecretory or Dahlgren cells: The Dahlgren cells are present on either side of the central canal in dorsal and dorsolateral positions. These cells form clusters in the region of the urophysis. Their presence in the region of the spinal cord anterior to the urophysis was not determined. In other fishes the Dahlgren cells extend upto 6th vertebral region from the spinal cord as counted from the tail end. In Xenentodon, however, the concentration of Dahlgren cells (DAHL. Figs. 7 and 8 ) is more in the rogion of urophysis itself. The Dahlgren cells are comparatively larger in size measuring about 7 to $9 \mu$. They are strongly basophilic. The nucleus is mainly oval or ovoid. In maturing Dahlgren cells, the nucleus is round. It is surrounded by a thick nuclear membrane. The nucleoplasm is more concentrated towards the periphery. In many Dahlgren cells the peripheral nucleoplasm sends out small processes towards the centre of the nucleus. The central part of the nucleus takes little or no stain. In this chromophobic area is found a single nucleolus. At the ends of the nucleoplasmic processes as wall as in the central part of the nucleus are found minute deeply staining basophilic granules. The nucleoplasm takes a light pinkish stain with haematoxylin and eosin suggesting some acidophilic material inside but that may be due to the change in the secretory phase of the cell. As already mentioned these cells are mainly basophilic in nature. It is only in the peripheral portion of the nucleus that the minute chromatin granules are visible. The Dahlgren cells in Xenentodon are mostly unipolar. Only a few bipolar cells were evident in the sections.

(ii) Urophysis proper (URO. PR. Fig. 7): It has a covering membrane which is distinct from that of spinal cord. Extensions 
of the pia mater into the urophysis are not present in this fish.

In Esox and Lucius (Friedberg, 1962), meninx sheath penetrate into the urophysis at different levels. Favaro (1925) suggests naming the central part of the urophysis as medulla and the peripheral part as the cortex. These two regions are also distinguishable in Xenentodon. The processes from the Dahlgren cells pass into the urophysis from the spinal cord. These processes are situated ventral to the central canal and then they pass and ramify into the central portion of the urophysis (medulla). Thus the medullary portion of the urophysis consists mainly of processes of Dahlgren cells. The medullary portion has a vage resemblance to the neurohypophysis of the pituitary body. The main mass of the urophysis is formed of numerous blood capillaries in association with the processes of the Dahlgren cells and the connective tissue cells.

9. Islets of Langerhans (Fig. 12):

The endocrine portion of the pancreas is represented by a single islet of Langerhans (ISL. LAN. Fig. 12) which lies in the mesenteric portion of the pancreas. It is stained lighter than the exocrine cells by Bailey's (1937 c) and Gomori's (1941) stains and is surrounded by a thin membrane.

\section{Summary}

The endocrine glands in Xenentodon are hypophysis, pineal, thyroid, thymus, corpuscles of Stannius, interrenal, post-branchial, urophysis and the islets of Langerhans.

The pituitary has the usual structure, however, the pars intermedia is centrally situated. Such a condition has so far been reported in only a few teleosts. The pineal is an elongated structure with a definite stalk. Numerous pigment granules are found in the pineal cells. Thyroid follicles surround the ventral aorta in the pharyngeal region. Thymus is present inside the pharynx dorsal to the branchial region on each side. It is without a peduncle and has simple structure. There are two corpuscles of Stannius one on each side of the median line. The internal cavity in each is filled with lamellae of simple epithelial tissue. The outer capsular wall is made up of flattened cells and is not fibrous. The anterior portion of each kidney has become modified into the interrenal body. Although renal in origin the interrenal bodies appear to function as the endocrine organs in the adult. Post-branchial body lies squeezed between the oesophagus and the sinus venosus. Larger cells show lobulated nuclei. Urophysis forms a ventral enlargement at the caudal end of the 
spinal cord. There is great concentration of Dahlgren cells in the region of the Urophysis proper. The processes from these cells pass into the urophysis. Extensions of the pia mater into the urophysis are absent in this fish. There is a single islet of Langerhans. This endocrine portion of pancreas stains lighter than the exocrine portion.

\section{Acknowledgement}

We are thankful to Dr. H. N. Bhargava, Head of the Department of Zoology, for providing us the necessary facilities.

\section{References}

Bailey 1937 c. Journal of Pathology \& Bacteriology. London, Vol. 44 : p. 272 (fide' Gray, 1953).

Dahlgren, U. 1914. The electric motar nerve-center in the skates (Rajidae). Science, Vol. XL, No. 1401: 862 .

Davenport, H. A. 1960. Histological \& Histochemical Technics. W. B. Saunders Company Philadelphia.

Dawson, A. B. 1953. Evidence for the termination of neurasecretory fibres with in the pars intermedia of the hypophysis of the frog, Rana pipiens. Anat. Rec. $115: 63-67$.

Delafield 1885. Zeitschrift fur wissenschaftliche Mikroskopie und fur mikroskopische Technik. Leipzig, 2: p. 288 (fide' Gray, 1953).

Enami, M. 1959. The morphology and functional significance of the caudal neurosecretory system of fishes. Symposium on Comparative endocrinology held at Cold spring Harbor, 1958, Edit. A. Gorbman. J. Wiley \& Sons, Inc., New York: 697-724.

Favaro, G. 1925. Contributo allo studio morfologico dell'lpofisi caudale (rigonfiamento caudale della midolla Spinale) dei Teleostei. Mem. R. Accad. naz : Lincei. Vol. I : $30-72$.

Fridberg, G. 1959. A histological evidence of the homology between Dahlgren's cells in rays and teleosts. Acta. Zool. $40: 101-104$.

Fridberg, G. 1962. Studies on the Caudal Neurosecretory system in Teleosts. Acta. Zool. XLIII : 1-77.

1963. Morphological studies on the Caudal Neurosecretory System in Teleosts and Elasmobranchs. Thesis, Zool. Inst., Univ. Stockh : 1-20.

Garrett, F.D. 1942. The development and phylozeny of the corpuscles of Stannius in Ganoid and Teleostean fishes. J. of Morph, Vol. 70: p. 41-60.

Giacomini, E. 1934. Ulteriori richerche anatomo microscopiche ed organo genetiche sil sistema interrenale e sui Corpuscolidi Stannius dei Teleostei e dei Ganoidi. Rendi. R. Acad. Sci. Inst. Bologna., Vol. 38.

Gomori 1941. American Journal of Pathology. Boston, Vol. 17: p. 395 (fide' Gray, 1953).

Gorbman, A. 1965. Endocrine Terminologie Usage. Journal of Comparative endocrinology 5, 129-130.

Gray, P. 1953. 'The Microtomist's Formulary and Guide. Blakiston company, Inc. Newyork.

Green, J. D. 1951. The comparative anatomy of the hypophysis with special reference to its blood supply and innervation. Amm. J. Anat. 88 : 225-311. 
Gurr, E. 1958. Methods of Analytical Histology and Histochemistry, London.

Gupta, O. P. 1970 d. Studies on the functional morphology and anatomy of the Central Nervous System of Xenentodor cancila (Ham.) including its histology. Zool. Anz. Leipzig......(in processing).

Gupta, O. P. \& Shrivastava, R. K. 1971. Morpho-histological studies of the interrenal bodies, mesonephric kidneys and the urinary bladder of the Indian Gar-fish, $X$. cancila (Ham.) Okaj. Fol. anat. jap. 48 (4), 2 : 205-211.

Gunar, F. 1963. Morphological studies on the caudal neurosecretory System in teleosts. Acta, Zool. 19 p.

Hammer, J. A. 1908. Zur Kenntnis der Teleostierthymus. Arch. mikrosk. Anat. Vol. 73 , p. $1-68$.

Heidenhain, 1905. Zeitschrift fur wissenschaftliche Mikroskopie und fur mikroskopische Technik. Leipzig, Vol. 22 : p. 339 (fide' Gray, 1953).

Himes, M. \& Moriber, L. 1956. Stain Technology. Vol. 31, No. 2, Pages 67-70 (fide' Gurr, 1958).

Holmer, 1927. Benno. Mikroskopische Technik, 15th ed. Munich, Leibniz (fide' Gray, 1953).

Holmgren, U. 1959. On the caudal neurosecretory system of the Eel, Anguilla rostrata. Anat. Rec. 135 : $51-552$ pls. 2 figs.

- 1959. On the caudal neurosecretory system of the teleost fish, Fundulus heteroclitus L. Breviro No. 111 : pp. 1-13, 2 pls.

Jakson, S. 1922. The islets of Langerhans in Elasmobranch and Teleosteen Fishes. J. Metab. Research, Vol. 2, p. 141-147.

Kaur, S. 1968. The hypothalamo-hypophyseal system in fish in relation to the reproduction. Ph. D. Thesis Saugar University (Unpublished).

Korson, R. 1951. Stain'Technology. Vol 26, No. 4 pages 265-70 (fide' Gurr, 1958).

Krawarik, F. 1936. Uber eine bisher unbekannte Druse ohne Austithrungsgang bei den heimischen Knochenfischen. Z. mikroskop. anat. Forsch. 39, 555-609.

Lillie, R. D. 1951. American J. Clin. Path. Vol. 21, pages 484-8 (fide' Gurr, 1958).

Mallory, 1936. Stain Technology, Geneva. Newyork, 11 : p. 101 (fide' Gray, 1953).

Raizada, A. K. 1970. Studies on the pituitary gland of some Indian fresh water teleost fishes. Ph. D. Thesis, Saugar University....... (Unpublished).

Rasquin, P. \& Rosenbloom, L. 1954. Endocrine imbalance and tissue hyperplasia in teleosts maintained in darkness. Bull. Am. Museum Nat. Hist. 104, 359-426.

Romeis, 1948. Benno. Mikroskopische Technik, 15thed. Munich, Leibniz (fide' Gray, 1953).

Vincent, S. W. \& Curtis, F.R. 1927. A note on the Teleostean adrenal bodies. J. Anat. Physiol. Vol. 62, p. 110-114.

Vivien, J.H. 1941. Contribution a' l'ètude de la physiologie hypophysaire dans ses relations avec l'appareil gènital, la thyroide et les Corps interrénaux chez les Poissons sélaciens et Téléosteens. Bull. Biol. Fr. Belg., Vol. 75, p. 257-309.

Yamamoto, Y. 1960. Comparative histological studies of the thyroid gland of lower vertebrates. Okajimas Folia anat. Jap. $34: 353-381,3$ pls.

Weigert-Pal (Clark \& Ward) 1934. Stain Technology, Geneva. Newyork, Vol. 9 : p. 34 (fide' Davenport 1960).

Wiesel, 1902. Anatomische Hefte: Abteilung 1. Wiesbaden, Vol. 19: p. 481 (fide' Gray, 1953). 


\section{Explanation to Plate I}

Fig. 1. Xenentodon adult: Median longitudinal section of hypophysis. $\times 60$

Fig. 2. Xenentodon, $110 \mathrm{~mm}$. W.1.: T.S. of lower jaw passing through the ventral aorta and showing the thyroid follicles. $\times 240$

Fig. 3. Xenentodon, $35 \mathrm{~mm}$. W.1.: T.S. of thymus. $\times 120$

Fig. 4. Xenentodon adult: T.S. of a corpuscle of Stannius. $\times 36$

Fig. 5. Xenentodon, $110 \mathrm{~mm}$. W. 1.: T. S. passing through the oesophageal region showing clusters of ultimobranchial cells. $\times 270$

Fig. 6. Xenentodon, $35 \mathrm{~mm}$. W.1.: T. S. of urophysis. $\times 270$

Abbreviations :

AUD. CAP. C. MAR.

COL.

COV. M.

EP.

EP. C.

FOL. EP.

G.

INF. R.

M. MEM.

OES: $M$.

PI.

PN.

PPD.

RPD.

SCATT. N. PN. TH. FOL.

SV.

ULTI. C.

URO.

V. AO.
Auditory capsule

Mass of cells

Colloid

Covering membrane

Epithelium

Epithelial cells

Follicular epithelium

Gills

Infundibulum recessus

Mucous membrane

Oesophageal muscles

Pars intermedia

Pars nervosa

Proximal pars distalis

Rostral pars distalis

Scattered nuclei of pituicytes in the neurohypophysis

Thyroid follicles

Sinus venosus

Ultimobranchial cells

Urophysis proper

Ventral aorta 


\section{Explanation to Plate II}

Fig. 7. Xenentodon adult: L.S. of urophysis showing urophysis proper and Dahlgren's cells. $\times 270$

Fig. 8. Xenentodon adult: T.S. of urophysis showing Dahlgren cells (enlarged). $\times 270$

Fig. 9. Xenentodon adult: T.S. of interrenal. $\times 270$

Fig. 10. Xenentodon adult: A portion of the T.S. of pineal body. $\times 270$

Fig. 11. Xenentodon adult: L. S. of brain showing velum transversum, paraphysis, pineal and haebenular ganglia. $\times 37$

Fig. 12. Xenentodon adult: T.S. of pancreas passing through the islet of Langerhains. $\times 150$

Abbreviations :

DAHL.

Dahlgren cells

EXO. PANC. Exocrine pancreas

GANG. C.

Ganglion cells

HAB. G.

Haebenular ganglion

ISL. LAN.

Islet of Langerhans

NSC.

Neurosensory cells

PANC. D. Pancreatic duct

PAR.

Paraphysis

PIN.

Pineal

P. NEP. D.

Pronephric duct

PSEUD. $T$.

Pseudoly mphoid tissue

URO. PR.

Urophysis proper

VT.

Velum transversum

ZY. GRA.

Zymogen granules 


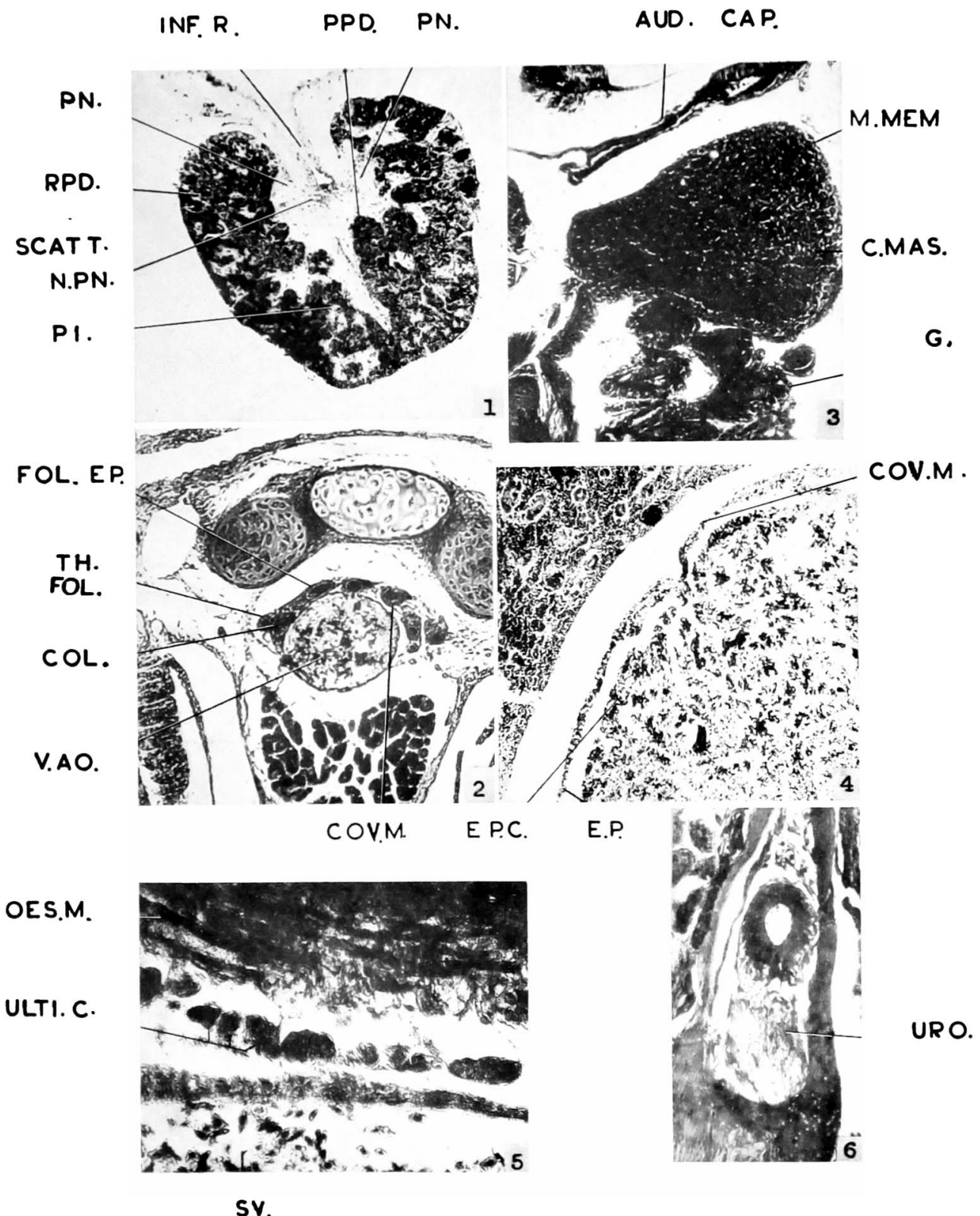




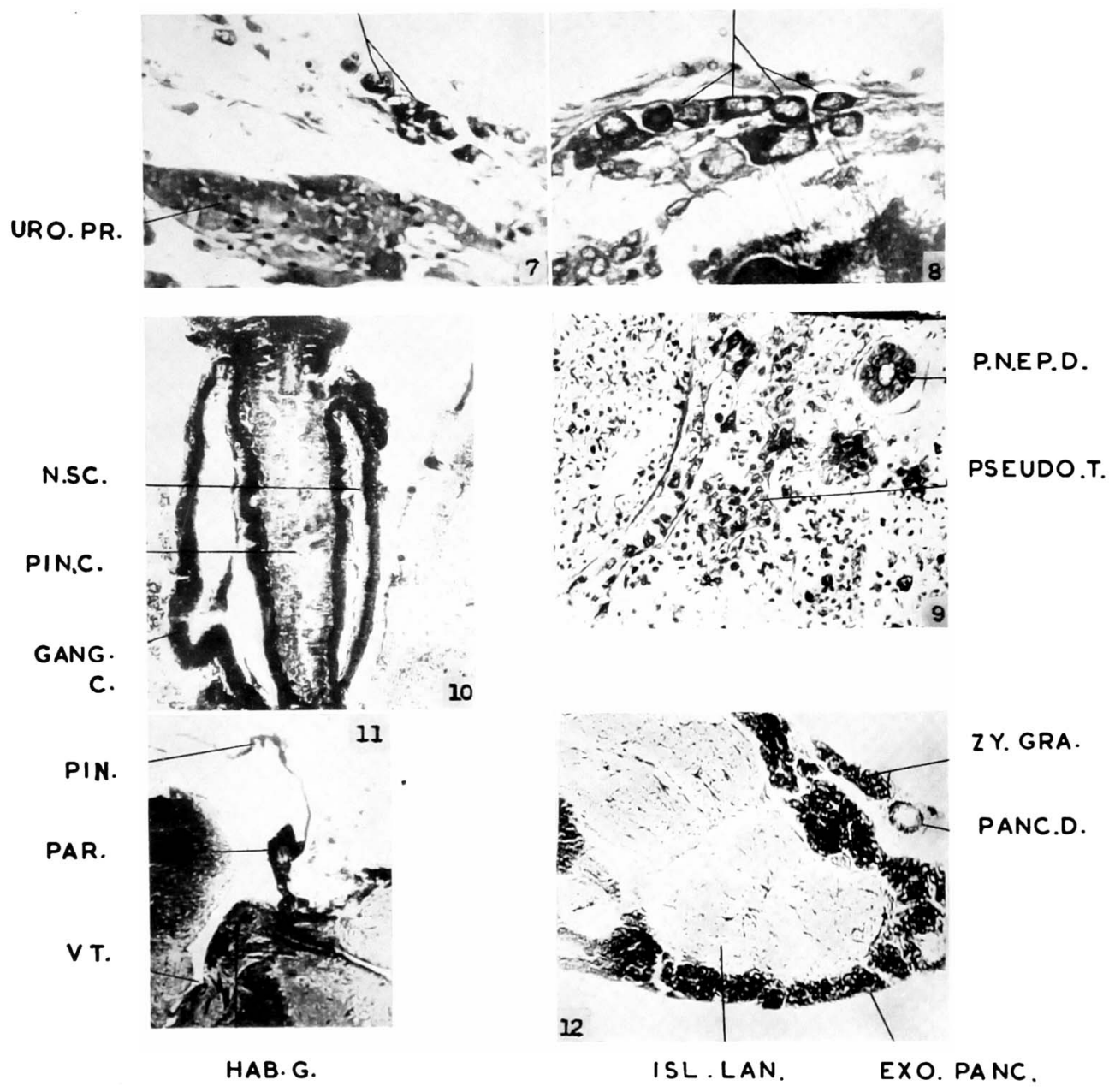

